\title{
REMOVAL OF METHYLENE BLUE BY ADSORPTION ONTO ACTIVATED CARBONS PRODUCED FROM AGRICULTURAL W ASTES BY MICROW AVE INDUCED KOH ACTIVATION
}

\author{
Ibtissem Kahoul1, 2, * Nabil Bougdah¹, Faycal Djazi1, 2, Chahrazed Djilani², \\ Pierre Magri ${ }^{3}$, Mohamed Salah Medjram ${ }^{1,4}$
}

https://doi.org/10.23939/chcht13.03.365

\begin{abstract}
The present study aims to describe new low cost activated carbons which were prepared from bean peel (BP), acorn peel (AP) and Pistacia lentiscus (PL) under microwave induced $\mathrm{KOH}$ chemical activation for the removal of methylene blue dye from aqueous solutions. Activated carbons were characterized using, thermogravimetric analysis, and scanning electron microscopy. The adsorption properties were examined considering several parameters including the effect of $\mathrm{pH}$, contact time, adsorbent dosage and initial concentration. Activated carbons powders prepared from BP, AP and PL can be used as an eco-efficient and low-cost adsorbent for removing methylene blue dye from aqueous solution by adsorption process.
\end{abstract}

Keywords: activated carbon, agricultural wastes, adsorption, methylene blue, microwave.

\section{Introduction}

Wastewater effluents released from different industries such as textile, paper, rubber, leather, plastics, cosmetic, and printing contain several classes of synthetic dyestuffs [1].

Dyes are mainly used in the textile industry, although substantial quantities are consumed for coloring different materials, such as paper, leather, plastics, petroleum products, and food [2].

Methylene blue is the most common dye used in the dyeing of wood, cotton, and silk. It can cause eye

\footnotetext{
${ }^{1}$ Department of Petrochemistry and Process Engineering, Faculty of Technology,

University 20 August 1955-Skikda, Algeria

${ }^{2}$ Laboratory LRPCSI, University 20 August 1955 -Skikda, Algeria

${ }^{3}$ LCP-A2MC, University of Lorraine, 1, bd Arago-57078 METZ,

Cedex 3, France

${ }^{4}$ Laboratory LGCES, University 20 August 1955-Skikda, Algeria

*ibtissem-k21@hotmail.fr

(C) Kahoul I., Bougdah N., Djazi F., Djilani C., Magri P., Medjram M. S., 2019
}

injury to humans and animals. Its inhalation may lead to breathing difficulties while mouth ingestion induces burning, nausea, vomiting, sweating, and abundant cold sweats [3]. The treatment of industrial waste containing this type of dye is of a great interest.

A wide variety of physical, chemical and biological techniques have been developed and tested for the sake of treatment of effluents loaded with dyes. These processes include flocculation, precipitation, ion exchange, membrane filtration, irradiation, and ozonation. However, these methods are expensive and result in generation of large quantities of formed derivatives [4].

Among the processes of treatment of the liquid rejections, adsorption remains a technique relatively used and easy to implement. Adsorption is usually used to treat wastewater due to the efficient elimination of organic micropollutants and owing to economic considerations $[5,6]$.

The objective of this work was to test the efficiency of new activated carbons obtained from agricultural wastes, namely bean peel, acorn peel and Pistacia lentiscus under microwave induced $\mathrm{KOH}$ chemical activation for removing of cationic dye which is methylene blue from aqueous solutions by adsorption process.

\section{Experimental}

\subsection{Preparation of Adsorbate}

Methylene blue (MB), a basic dye having a molecular structure as $\mathrm{C} 16 \mathrm{H} 18 \mathrm{~N} 3 \mathrm{SCl}$ (with a molecular weight of $319.85 \mathrm{~g} / \mathrm{mol}$, and $\lambda_{\max } 665 \mathrm{~nm}$ ) was used in this work. The stock dye solution was prepared by dissolving accurately weighed dye in the deionized water to the concentration of $100 \mathrm{mg} / \mathrm{l}$ and subsequently, the experimental solutions of various initial concentrations $\left(C_{0}\right)$ were prepared by diluting stock solution to the desired concentrations. 


\subsection{Preparation of Activated Carbons}

Bean peel (BP), acorn peel (AP) and Pistacia lentiscus (PL) were collected in the northeastern region of Algeria. After collecting, these adsorbents were cut into small pieces with a clean chisel, then washed thoroughly with distilled water to remove dirtiness, dried in sunlight, and finally crushed and filtered at $250 \mu \mathrm{m}$.

Pistacia lentiscus was soaked in hexane to remove residual oils, then filtered and washed several times with distilled water, dried in an oven at $353 \mathrm{~K}$ for $12 \mathrm{~h}$, and cooled at a room temperature. After that, BP, AP and PL were carbonized at 623,923 and $853 \mathrm{~K}$, respectively, for $1 \mathrm{~h}$ in an oven. The chars produced were soaked in potassium hydroxide solution with an impregnation (char: $\mathrm{KOH}$ ratio was 1:1.75\% w/w) [7].

The activation step was carried out in glass tubes placed in a microwave oven (Monowave Extra Anton Paar MAS24 type; the frequency $2.45 \mathrm{GHz}$ ). The microwave power was adjusted at $800 \mathrm{~W}$, the irradiation time was selected as 7 min for each sample, and the stirring speed was set at $600 \mathrm{rpm}$ [8].

The activated products were then washed with hydrochloric acid of $0.1 \mathrm{M}$ and deionized water until the $\mathrm{pH}$ of the washing solution reached 7-8, then they were filtered and dried in an oven at $333 \mathrm{~K}$ for about $12 \mathrm{~h}$ [9].

\subsection{Characterization}

The thermal decomposition of BP, AP and PL was studied using thermal balance 2050 TGA v5.4 A from TA Instruments. In order to visualize the morphology of the activated carbons before and after the activation process, we have used scanning electron microscopy (TESCAN type).

\section{Results and Discussion}

\subsection{Characterization of the Adsorbent}

\subsubsection{Thermogravimetric analyses}

Thermal decomposition curves are illustrated below in Fig. 1.

TGA thermal curve that corresponds to BP (Fig. 1a), comprises four stages of the mass loss process. The first weight loss of $11.5 \%$ is due to the release of the adsorbed water at $329 \mathrm{~K}$. Next, three other peaks follow: the decomposition reaction with weight loss of about $28 \%$ was observed at $563 \mathrm{~K}$, which corresponds to the hemicellulose departure, also a weight loss of about $20 \%$ is observed at $598 \mathrm{~K}$, corresponding to the departure of the cellulose, while the last loss of about $14 \%$ took place at $713 \mathrm{~K}$, corresponding to the departure of the lignin $[10,11]$.
TGA thermal curve that corresponds to AP (Fig. 1b), contains four stages of the mass loss process. The first stage extends from the beginning of the analysis to $350 \mathrm{~K}$ with weight loss of about $11 \%$. Three other peaks follow at 558, 613 and $678 \mathrm{~K}$, with corresponding mass losses of 19,13 and $8 \%$ which indicates the thermal decompositions of the cellulose, hemicellulose, and lignin, respectively $[12,13]$.

TGA thermal curve that corresponds to PL is shown in Fig. 1c. Three stages of mass loss were observed. The first stage of weight loss $(2.42 \%)$ was observed at $337 \mathrm{~K}$, corresponding to the departure of the physisorbed water. The second stage that had a mass loss of $33 \%$ was observed at $551 \mathrm{~K}$, corresponding to the departure of the hemicellulose and cellulose. The last loss of about $8 \%$ occurs at $663 \mathrm{~K}$, corresponding to the departure of the lignin.
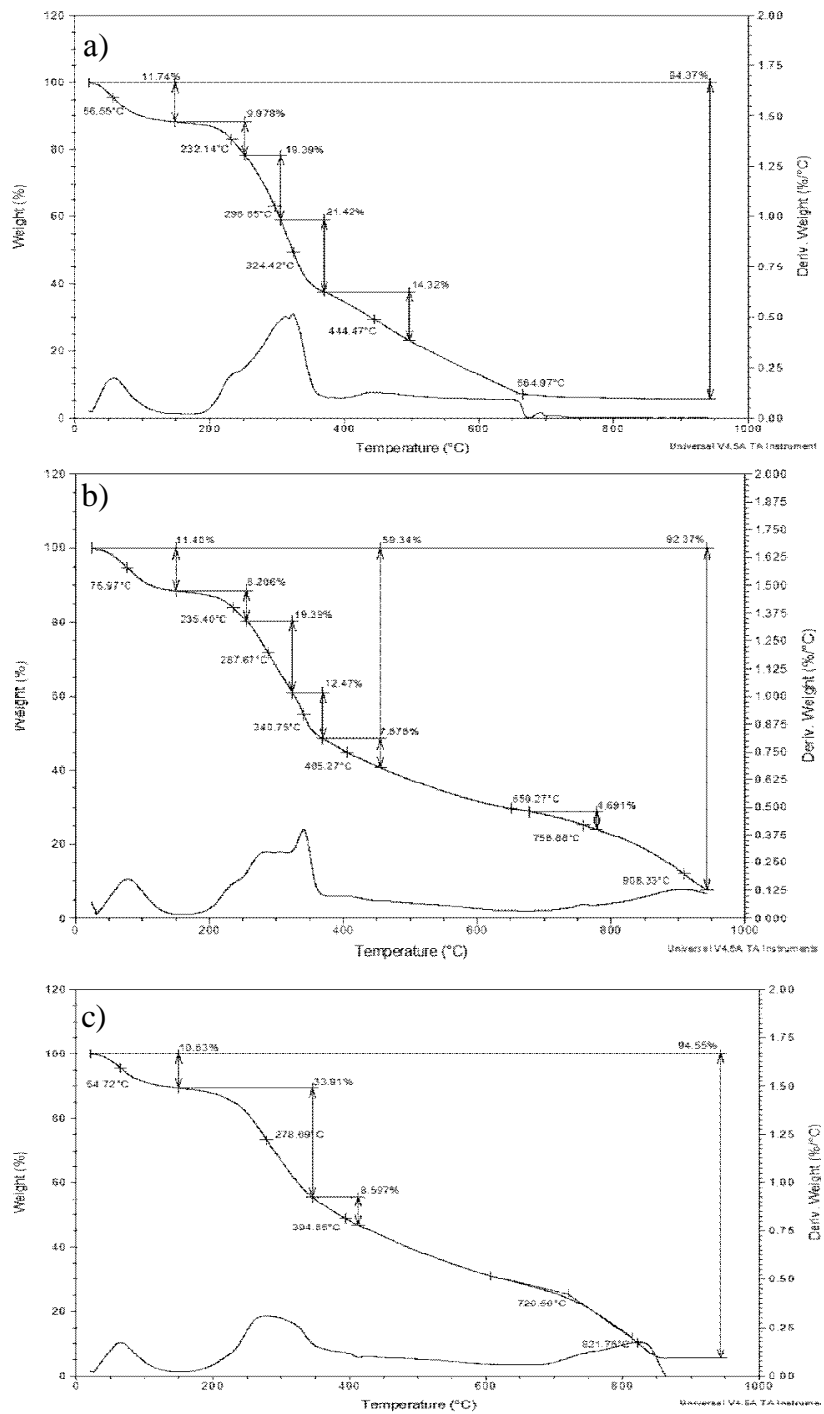

Fig. 1. TGA/DTG analysis of BP (a), AP (b) and PL (c) 


\subsubsection{Scanning electron microscopy studies}

In order to estimate the textual structure of adsorbents, scanning electron microscope analysis has been used before and after the activation process via microwave assisted $\mathrm{KOH}$ activation.

It can be seen that the surface morphology of activated carbon from BP (Fig. 3a) has developed uniform surface, forming an orderly pore structure.

However, the surface morphology of activated carbons from AP and PL was a gathering of fine particles, which has no regular and fixed shape and size. The

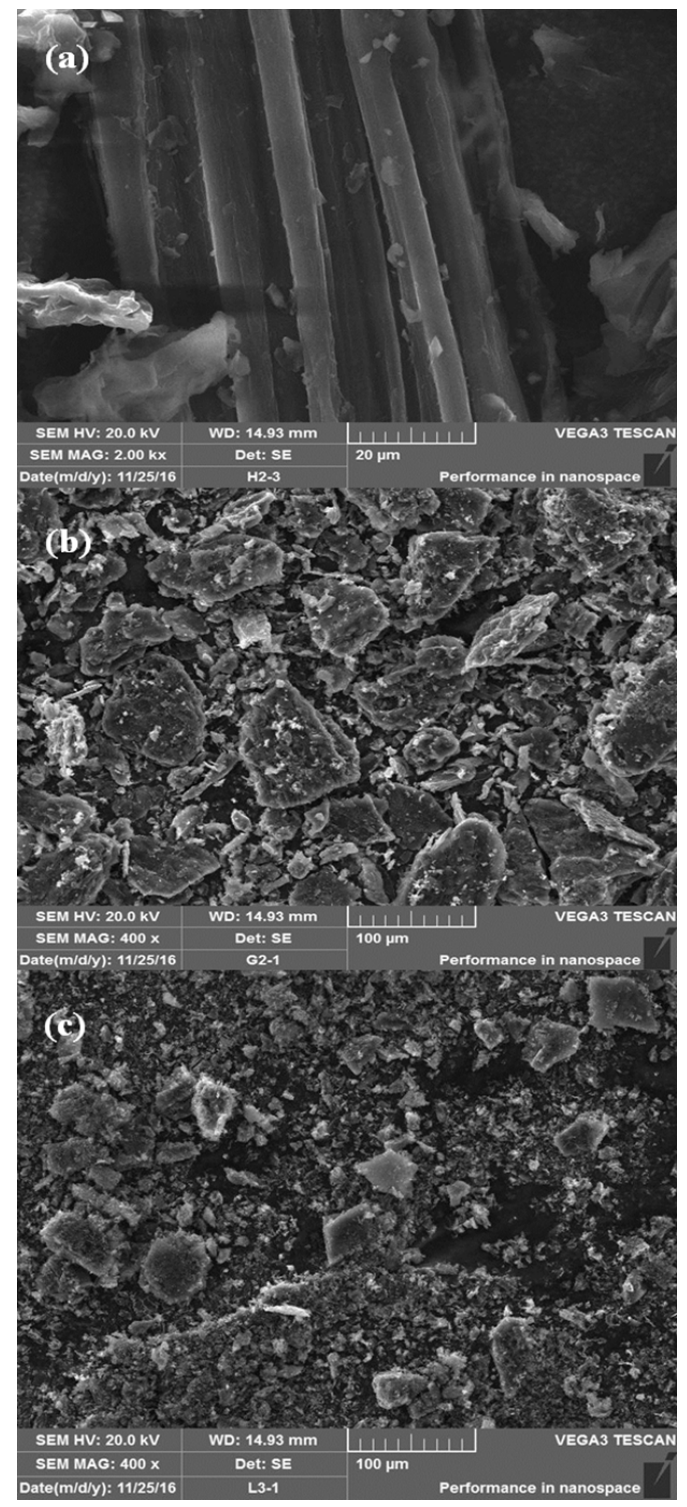

Fig. 2. SEM micrographs of chars: BP (a), AP (b) and PLC (c) particles were of different dimensions and included a large number of kinks on the external surface.

\subsection{Adsorption Kinetics Studies}

Kinetic experiments were carried out in Erlenmeyer flasks including $100 \mathrm{ml}$ aqueous solution of methylene blue with a known number of different adsorbents at ambient temperature. Solutions were stirred at $250 \mathrm{rpm}$ during selected laps time. After that, the solution was centrifuged in order to remove the adsorbent dispersion and analyzed by UV spectrometry (Analytik Jena (AG) spectrophotometer).

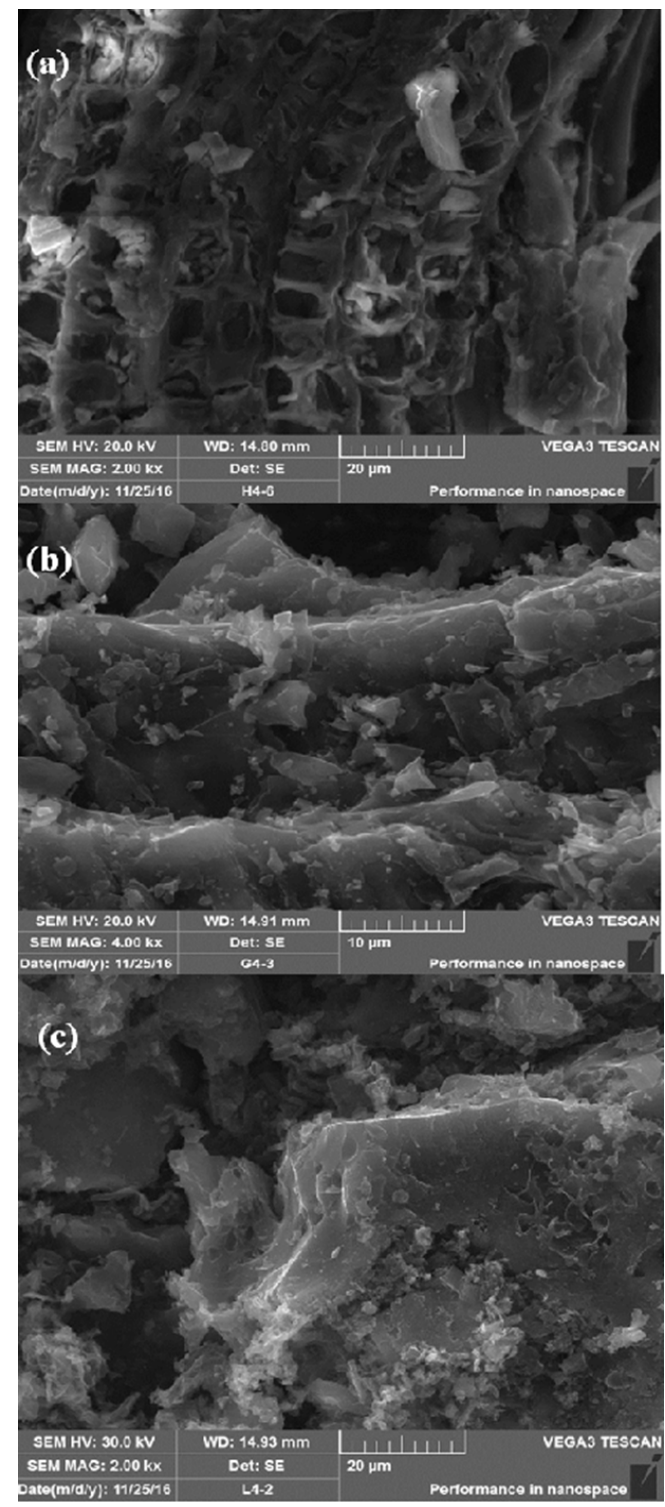

Fig. 3. SEM micrographs of activated carbons: BP (a), AP (b) and PL (c) 
The amount of dye adsorbed onto adsorbents at time $t, q_{t}(\mathrm{mg} / \mathrm{g})$ was computed by the mentioned mass balance relationship:

$$
\begin{aligned}
& q_{t}=\left(C_{0}-C_{e}\right) \cdot \frac{V}{m} \\
& R \%=\frac{\left(C_{0}-C_{e}\right)}{C_{0}} \cdot 100
\end{aligned}
$$

where $q_{t}$ is the adsorption capacity; $R \%$ is the adsorption percentage; $C_{0}$ and $C_{e}$ are the initial and equilibrium concentrations, $\mathrm{mg} / \mathrm{l} ; V$ is the volume of the solution, $\mathrm{l}$; $m$ is the mass of adsorbent used, $g$.

Fig. 4 presents the kinetics adsorption obtained at room temperature with the adsorbate initial concentration of $10 \mathrm{mg} / \mathrm{l}$. The mass of activated carbons was $50 \mathrm{mg}$ within all experiments.

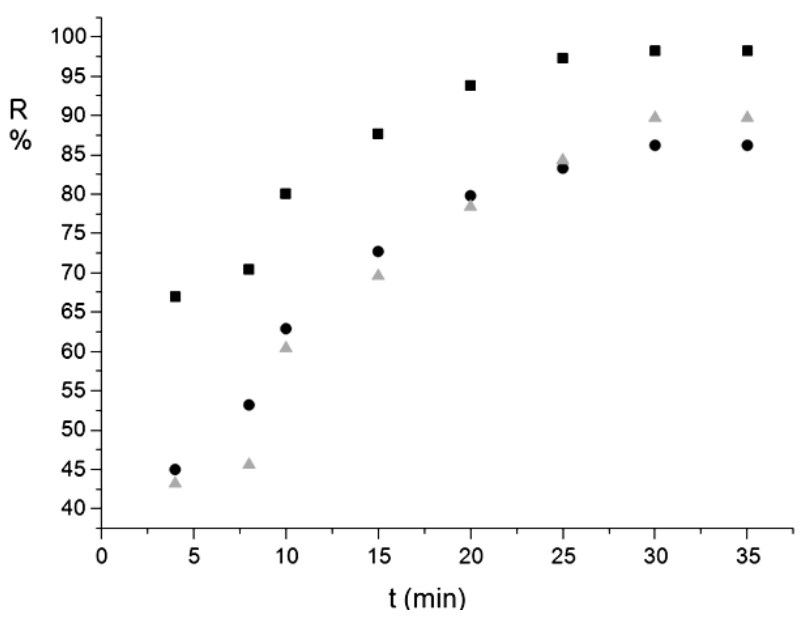

Fig. 4. Kinetics adsorption $M B$ on $\mathrm{BP}(\mathrm{n}), \mathrm{AP}(\bullet)$ and PL (

Fig. 4 shows the variation of the adsorbed MB amount as a function of time on BP, AP, and PL. It can be seen from Fig. 4 that the adsorption efficiency increases with the contact time because a large number of vacant surface sites are present for adsorption. Equilibrium is reached for three adsorbents after $30 \mathrm{~min}$. The maximum adsorption percentage for activated carbons was $98.2 \%$ for BP, $86.2 \%$ for AP and $89.7 \%$ for PL.
Kinetic studies are important to estimate the efficiency and mechanism of sorption process. Adsorption kinetics defines the nature of adsorption interaction dependence of the adsorbents with species [14].

Constants from two kinetic models, pseudo firstorder and pseudo second-order ones, were fit for experimental data to examine the adsorption of MB by activated carbons $\mathrm{BP}, \mathrm{AP}$ and PL.

The first one was the linear form of the pseudo first-order model of Lagergren [15, 16], generally expressed as follows:

$$
\operatorname{Ln}\left(q_{e}-q_{t}\right)=\operatorname{Ln}\left(q_{e}\right)-k_{1} t
$$

where $q_{e}$ and $q_{t}$ are the amounts of MB adsorbed at equilibrium and after time $t$, respectively. We noticed the rate constant of adsorption as $k_{1}, \min ^{-1}$.

The pseudo-second-order model [17]:

$$
\frac{d q t}{d t}=k_{2}(q e-q t)^{2}
$$

where $k_{2}$ is the equilibrium rate constant of the pseudosecond-order, $\mathrm{g} \cdot \mathrm{mg}^{-1} \cdot \mathrm{min}^{-1}$.

We separated variables in Eq. (4) and then integrated for the boundary conditions $q_{t}=0$ to $q_{t}=q_{t}$ and $t=0$ to $t=t$ yields to the expression that we can rearrange to the following linear formula:

$$
\frac{t}{q_{t}}=\frac{1}{k_{2} q_{e}^{2}}+\frac{t}{q_{e}}
$$

The slope and the intercept allow us to establish $q_{e}$ and $k_{2}$, respectively.

Kinetic model parameters together with $R^{2}$ correlation coefficients are presented in Table 1.

The pseudo-second-order model gives a better fit. The correlation coefficients of the pseudo-second-order kinetics have higher values than those of the pseudo-firstorder. Moreover, the value of $q_{e}$ obtained with pseudosecond-order model is in a good agreement with the experimental value of $q_{e}$ exp. Therefore, the adsorption of MB onto activated carbons BP, AP and PL follows second-order reaction kinetics.

The results propose that the adsorption of MB takes the path of the pseudo-second-order kinetics, showing that the rate-determining step of the adsorption process can be chemical adsorption or chemisorption [18].

Table 1

Pseudo-first order and pseudo-second-order kinetics parameters of BP, AP, and PL

\begin{tabular}{|c|c|c|c|c|c|c|c|}
\hline \multirow{2}{*}{ Adsorbent } & \multicolumn{3}{|c|}{ Pseudo-first-order } & \multicolumn{3}{c|}{ Pseudo-second-order } \\
\cline { 2 - 8 } & $k_{1}, \mathrm{~min}^{-1}$ & $q_{\text {e calc }}, \mathrm{mg} / \mathrm{g}$ & $q_{\text {e exp }}, \mathrm{mg} / \mathrm{g}$ & $R^{2}$ & $k_{2}, \mathrm{~g} \cdot \mathrm{mg}^{-1} \cdot \mathrm{min}^{-1}$ & $q_{e \text { calc }}, \mathrm{mg} / \mathrm{g}$ & $R^{2}$ \\
\hline BP & 0.1598 & 17.34 & 19.64 & 0.90 & 0.0141 & 21.69 & 0.98 \\
\hline AP & 0.1288 & 16.33 & 17.24 & 0.98 & 0.0078 & 20.70 & 0.98 \\
\hline PL & 0.1051 & 17.15 & 17.94 & 0.96 & 0.0047 & 22.72 & 0.98 \\
\hline
\end{tabular}




\subsection{Adsorption Isotherms}

The adsorption isotherms of $\mathrm{MB}$ on activated carbons BP, AP, and PL have assessed the exact identical experimental setup as with kinetic experiments. In each experiment, samples of $50 \mathrm{mg}$ of $\mathrm{BP}, \mathrm{AP}$, and PL were equilibrated for $30 \mathrm{~min}$ at $298 \mathrm{~K}$ with $100 \mathrm{ml}$ of the dye aqueous solution of initial concentrations between 5 and $30 \mathrm{mg} / \mathrm{l}$.

The adsorption isotherms of $\mathrm{MB}$ on adsorbents are plotted in Fig. 5. We noted that they have a generally similar appearance, indicating that when the initial concentration of the MB increases, the adsorbed amount increases to almost a plateau indicating the saturation of all the sites on the adsorbents surface. The isotherms have been classified according to the classification of Giles et al. [19].

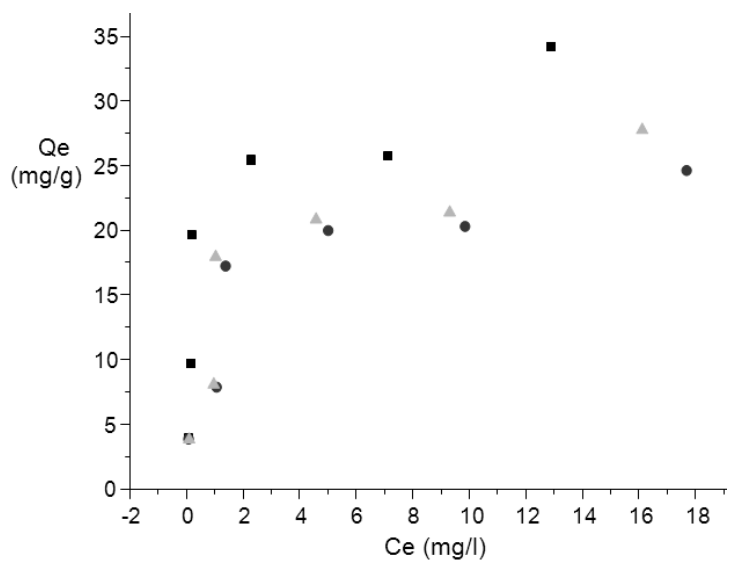

Fig. 5. Isotherms of $\mathrm{MB}$ on $\mathrm{BP}(\mathrm{n}), \mathrm{AP}(\bullet)$ and $\operatorname{PL}(\boldsymbol{\Delta})$

\subsubsection{Langmuir isotherm model}

The Langmuir model [20] presumes that an adsorption may happen at specific homogeneous sites on the adsorbent and is used successfully in many monolayer adsorption processes [21].

The Langmuir equation has the following form

$$
\frac{C_{e}}{q_{e}}=\frac{1}{q_{m} b}+\frac{C_{e}}{q_{m}}
$$

where $q_{m}$ is the theoretical maximum monolayer adsorption capacity, $\mathrm{mg} \cdot \mathrm{g}^{-1} ; b$ is the Langmuir constant, $1 \cdot \mathrm{mg}^{-1}$.

Langmuir isotherm can be expressed with respect to a dimensionless separation factor $R_{L}$, which is expressed as:

$$
R_{L}=\frac{1}{1+b C_{0}}
$$

where $C_{0}$ is the maximum initial MB concentration, $\mathrm{mg} / \mathrm{l}$.

The value of $R_{L}$ points to the shape of Langmuir isotherm to be either unfavorable $\left(R_{L}>1\right)$, linear $\left(R_{L}=1\right)$, irreversible $\left(R_{L}=0\right)$, or favorable $\left(0<R_{L}<1\right)$.

\subsubsection{Freundlich isotherm model}

Freundlich isotherm is settled on the assumption of a heterogeneous surface with a non-uniform heat distribution of the sorption on the surface [22, 23].

The Freundlich model is expressed as follows:

$$
q_{e}=K_{F} C_{e}^{1 / n}
$$

where $K_{F}\left(\mathrm{mg} \cdot \mathrm{g}^{-1} \cdot\left(1 \cdot \mathrm{mg}^{-1}\right)^{1 / n}\right)$ and $n$ are Freundlich constants related to the multilayer adsorption capacity and the surface heterogeneity, respectively. If $(n<1)$ the adsorption is unfavorable, $(n=1)$ the adsorption is homogeneous and $(n>1)$ the adsorption is favorable.

All of the correlation coefficients and the constants calculated from both models are listed in Table 2.

We can notice from Table 2 that the correlation factor $R^{2}$ is close to the unity for both models, however with a better fit of the experimental data [21].

It can be seen that the values of Freundlich constant $n$ are over 2 , which indicates that $\mathrm{BP}, \mathrm{AP}$, and $\mathrm{PA}$ are good adsorbents for MB.

The value of $R_{L}$ between $0-1$ proves that the adsorption of the MB on BPA, APA and PLA is favorable.

\subsection{Effect of pH}

$\mathrm{pH}$ of $\mathrm{MB}$ solution has been detected to be one of the most important factors affecting sorption process because of its influence on surface charge of adsorbent and solubility of MB [24, 25].

The influence of $\mathrm{pH}$ on the $\mathrm{MB}$ adsorption was studied for the different adsorbents. For this purpose, $100 \mathrm{ml}$ of $10 \mathrm{mg} / \mathrm{l}$ solution contaminated with $\mathrm{MB}$ and the optimum dose of the adsorbent were introduced. Each solution was stirred for a time corresponding to the equilibrium time of the dye, and the value of $\mathrm{pH}$ was varied. The acidic and basic $\mathrm{pH}$ values obtained were justified by the addition of $1 \mathrm{M} \mathrm{HCl}$ to acidify and $1 \mathrm{M}$ $\mathrm{NaOH}$ to basify.

Table 2

Langmuir and Freundlich isotherm parameters for MB adsorption

\begin{tabular}{|c|c|c|c|c|c|c|c|}
\hline \multirow{2}{*}{ Adsorbent } & \multicolumn{3}{|c|}{ Langmuir } & \multicolumn{3}{c|}{ Freundlich } \\
\cline { 2 - 7 } & $q_{m}, \mathrm{mg} \cdot \mathrm{g}^{-1}$ & $b, 1 \cdot \mathrm{mg}^{-1}$ & $R^{2}$ & $R_{L}$ & $K_{F}, \mathrm{mg} \cdot \mathrm{g}^{-1} \cdot\left(1 \cdot \mathrm{mg}^{-1}\right)^{1 / n}$ & $n$ & $R^{2}$ \\
\hline BP & 45.45 & 1.83 & 0.93 & 0.051 & 16.726 & 3.215 & 0.73 \\
\hline AP & 17.54 & 4.38 & 0.90 & 0.022 & 10.175 & 2.932 & 0.89 \\
\hline PL & 19.60 & 2.68 & 0.92 & 0.035 & 10.633 & 2.702 & 0.86 \\
\hline
\end{tabular}


Fig. 6 shows the variation of MB removal on BP, $\mathrm{AP}$, and $\mathrm{PL}$ at various initial $\mathrm{pH}$ of the solution.

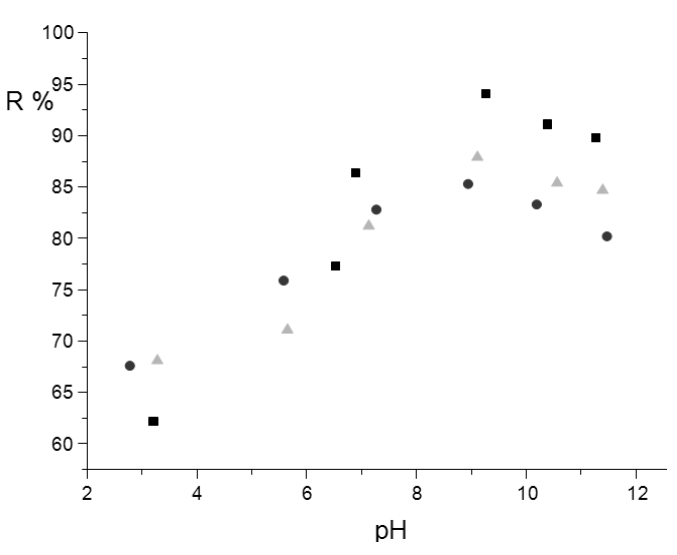

Fig. 6. Influence of $\mathrm{pH}$ on the adsorption yield on $\operatorname{BP}(\mathrm{n}), \mathrm{AP}(\bullet)$ and $\operatorname{PL}(\boldsymbol{\Delta})$

The behavior of MB dye adsorption on three activated carbons was studied over a wide range of $\mathrm{pH}$ $(2-12)$. It can be seen from Fig. 6 that the maximum quantity of MB removal for three adsorbents was at $\mathrm{pH} 9$; after that we can notice a decrease in the adsorbed capacity of the MB between $\mathrm{pH} 10$ and 12 . This behavior may be due to the fact that the surface of the adsorbents at $\mathrm{pH}<9$ is negatively charged, which promotes the adsorption of the methylene blue cationic dye. On the other hand, for $\mathrm{pH}$ values above 9, the surface of the adsorbents is positively charged and therefore capable of repelling the dye cations.

As the $\mathrm{pH}$ value decreases, the number of negatively charged sites also diminishes and the number of positively charged sites increases [26].

\section{Conclusions}

In this work, we have demonstrated that activated carbons prepared from agricultural wastes of bean peel, acorn peel and Pistacia lentiscus under microwave induced $\mathrm{KOH}$ chemical activation are good adsorbents for the removal of methylene blue from aqueous solutions. Equilibrium is reached for all activated carbons BP, AP, PL after $30 \mathrm{~min}$. The elimination ratios of these compounds were ranged from 86.2 to $98.2 \%$ for all new activated carbons BP, AP, and PL. The experimental adsorption data of Langmuir and Freundlich isotherm model have proven that the adsorption of MB on BP, AP and PL is favorable.

The calculated kinetic parameters of activated carbons BP, AP and PL from the pseudo first-order and pseudo second-order plots indicate that the pseudosecond-order model shows a better fit.
The attractive features of activated carbons via microwave assisted $\mathrm{KOH}$ can reduce the time and save energy for activated carbons preparation. Moreover, the activated carbons $\mathrm{BP}, \mathrm{AP}$, and $\mathrm{PL}$ are environment friendly, effective and of a low cost.

\section{References}

[1] Batzias F., Sidiras D.: Bioresour. Technol., 2007, 98, 1208. https://doi.org/10.1016/j.biortech.2006.05.020

[2] Tan I., Hameed B., Ahmad A.: Chem. Eng. J., 2007, 127, 111. https://doi.org/10.1016/j.cej.2006.09.010

[3] Ghosh D., Bhattacharyya K.: Appl. Clay Sci., 2002, 20, 295300. https://doi.org/10.1016/S0169-1317(01)00081-3

[4] Robinson T., McMullan G., Marchant R., Nigam P.: Bioresour. Technol., 2001, 77, 247. https://doi.org/10.1016/S09608524(00)00080-8

[5] Robinson T., Chandran B., Nigam P.: Water Res., 2002, 36, 2824. https://doi.org/10.1016/S0043-1354(01)00521-8

[6] Qi J., Li Z., Guo Y., Xu H.: Mater. Chem. Phys., 2004, 87, 96. https://doi.org/10.1016/j.matchemphys.2004.05.008

[7] Foo K., Hameed B.: Biomass Bioenerg., 2011, 35, 3257.

https://doi.org/10.1016/j.biombioe.2011.04.023

[8] Foo K., Hameed B.: Chem. Eng. J., 2012, 187, 53.

https://doi.org/10.1016/j.cej.2012.01.079

[9] Foo K., Hameed B.: Chem. Eng. J., 2012, 184, 57.

https://doi.org/10.1016/j.cej.2011.12.084

[10] Djilani C., Zaghdoudi R., Modarressi A. et al.: Chem. Eng. J., 2012, 189-190, 203. https://doi.org/10.1016/j.cej.2012.02.059

[11] Ozdemir I., Sahin M., Orhan R., Erdem M.: Technol., 2014, 125, 200.

[12] Farinella N., Matos G., Arruda M.: Technol., 2007, 98, 1940.

[13] Deiana A., Sardella M., Silva H. et al.: J. Hazard. Mater., 2009, 172,13. https://doi.org/10.1016/j.jhazmat.2009.06.095

[14] Ghaedi M., Biyareh M., Kokhdan S. et al.: Mater. Sci. Eng. C, 2012, 32, 725. https://doi.org/10.1016/j.msec.2012.01.015

[15] Zhu L., Chen B., Shen X.: Environ. Sci. Technol., 2000, 34, 468. https://doi.org/10.1021/es990177x

[16] Dogan M., Ozdemir Y., Alkan M.: Dyes Pigments, 2007, 75, 701. https://doi.org/10.1016/j.dyepig.2006.07.023

[17] Eftekhari S., Habibi-Yangjeh A., Sohrabnezhad S.: J. Hazard. Mater., 2010, 178, 349.

https://doi.org/10.1016/j.jhazmat.2010.01.086

[18] Dawood S., Kanti Sen T.: Water Res., 2012, 46, 1933. https://doi.org/10.1016/j.watres.2012.01.009

[19] Giles C., MacEwan T., Nakhwa S., Smith D.: J. Chem. Soc., 1960, 10, 3973. https://doi.org/10.1039/jr9600003973

[20] Gurses A., Dogar C., Yalcin M. et al.: J. Hazard. Mater., 2006, 131, 217. https://doi.org/10.1016/j.jhazmat.2005.09.036

[21] Langmuir I.: J. Am. Chem. Soc., 1918, 40, 1361. https://doi.org/10.1021/ja02242a004

[22] Mechati F., Bouchelta C., Medjram M. et al.: J. Environ. Chem. Eng., 2015, 3, 1928.

https://doi.org/10.1016/j.jece.2015.07.007

[23] Hamdaoui O., Naffrechoux E.: J. Hazard. Mater., 2007, 147, 381. https://doi.org/10.1016/j.jhazmat.2007.01.021

[24] Abuzer C., Gizem Ilgun E., Bozkurt H.: Chem. Eng. J., 2012, 191, 228. https://doi.org/10.1016/j.cej.2012.03.007

[25] Kumar P., Ramalingam S., Senthamarai C. et al.: Desalin., 2010, 261, 52. https://doi.org/10.1016/j.desal.2010.05.032 
[26] Tahir S., Rauf N.: Chemosphere, 2006, 63, 1842. https://doi.org/10.1016/j.chemosphere.2005.10.033

Received: March 29, 2018 / Revised: April 20, 2018 / Accepted: September 12, 2018

\section{ВИДАЛЕННЯ МЕТИЛЕНОВОГО СИНЬОГО АДСОРБЦІЄЮ НА АКТИВОВАНОМУ ВУГІЛЛІ ОДЕРЖАНОГО З СІЛЬСЬКОГОСПОДАРСЬКИХ ВІДХОДІВ ПІД ДІЕЮ АКТИВОВАНОГО МІКРОХВИЛЯМИ КОН}

Анотація. Для видалення барвника метиленового синього з водних розчинів досліджено нове недороге активоване вугілля, одержане з лушпиння бобів (ЛБ), жолудя (ЛЖ) та мастикового дерева (ЛМ) під дією активованого мікрохвилями КОН. Проведено аналіз одержаних зразків з використанням термогравіметричного аналізу та скануючої електронної мікроскопії. Адсорбиійні властивості вуглещю визначені 3 урахуванням впливу рН, часу контакту, кількості адсорбента та його початкової концентрації. Показано можслвість використання ЛБ, ЛЖ та ЛМ як екологічних ефективних та недорогих адсорбентів для видалення метиленового синього барвника з водного розчину.

Ключові слова: активоване вугілля, сільськогосподарські відходи, адсорбиія, метиленовий синій, мікрохвилі. 